\title{
Critical Analysis of Pakistan Automobile Industry From 1995 to 2005
}

\author{
Muhammad Aqil1, Syed Fazal Aziz2, Muhammed Dilshad3, Seemab Qadeer4 \\ ${ }^{1}$ (Assistant Professor, Commerce Department, Defence Authority Degree College, Karachi, Pakistan) \\ ${ }^{2}$ (Senior Executive Vice President(retd), National Bank of Pakistan, Karachi, Pakistan) \\ ${ }^{3}$ (Lecture, Government Degree College, Paretabad, Hyderabad, Pakistan) \\ ${ }^{4}$ (Assistant Professor, Economics Department, Defence Authority Degree College, Karachi, Pakistan)
}

\begin{abstract}
The automobile industry is one of the most important industries in large scale manufacturing sector. The automobile industry in Pakistan performed very well during the period of 1995 and 2005. However, there were many areas where the performance of industry was not up to the mark. This paper identifies the areas where this sector needs improvements. The analysis reveals that the industry did not have proper capacity utilization facility, it failed to offer competitive environment, it worked with low level of indigenization, it was suffered from inconsistent policies, it could not properly exploited consumers' demand and it failed to protect consumers' sovereignty.
\end{abstract}

Keywords: automobile industry, capacity utilization, consumers' demand, inconsistent policies, indigenization

\section{Introduction}

The vehicle Industry in Pakistan emerged as one of the rapidly growing sectors during last couple of years. The sector affected the economy positively from various aspects. The industry contributed a lot to GDP, it generated direct and indirect employment, it gave birth to many subsidiary industries. Apart from these positive aspects, there are many questions on the performance of this industry. For instance, the industry was unable to achieve adequate indigenization level in spite of high protection rate. In addition to this, the role of regulatory authorities (such as PAMA, PAAPAM and CBR) was ineffective and the bodies are unable to provide a proper direction to the sector. The industry was also not able to protect consumers' sovereignty as the industry has an oligopoly structure. The objective of this paper is to analyze the progress of the automobile industry critically from the period of 1995 to 2010 .

\section{Problems In The Automobile Industry}

\subsection{Less Competitive Structure}

The behavior of a firm depends upon the structure of market to a great extent. For instance, the performance of a firm in a laissez fair market would be different if the firm is working in a closed economy. Likewise, a firm may book large amount of returns in monopoly and may fail to sustain the profit level in a monopolistic competition market. All of these variations are applicable for the automobile industry in Pakistan.

As far as the Automobile Industry of Pakistan is concerned, the sector had enjoyed good protection against the foreign competition by means of tariff and non-tariff barriers. Therefore, the Original Equipment Manufacturers could not offer a competitive environment as there was a very tight monopoly or oligopoly structure in the market. For instance, Pak Suzuki Company enjoyed monopoly in the manufacturing and supply of $800 \mathrm{cc}$ and $1000 \mathrm{cc}$ vehicles during 1995-2005. Whereas Toyota and Honda companies formed a duopoly in the manufacturing of above $1000 \mathrm{cc}$ cars. Hino Pak Motors appeared as a dominant firm in the trucks and buses sector while Millat Tractors claimed a lion share in the manufacturing and supply of the Agricultural Tractors. This picture is portrayed by the above table 1 . The table depicts that the automobile market was governed by very few Original Equipment Manufacturers and the market lacked a free and healthy competitive environment.

Table 1: Market share of leading companies (2005)

\begin{tabular}{|l|l|l|l|}
\hline Vehicle type & Vehicle name & Company & Market share \\
\hline Car-1300 2000cc & Toyota Corolla & Indus Motors & $42.99 \%$ \\
\hline Car-1000cc & Cultus & Pak Suzuki & $45.85 \%$ \\
\hline Car-800 cc & Mehran & Pak Suzuki & $66.31 \%$ \\
\hline Jeep-4*4 & Potohar & Pak Suzuki & $73.12 \%$ \\
\hline Pick up/L.C.V. & Shehzore & Hyundai & $49.15 \%$ \\
\hline Motorcycle & Honda & Honda & $68.85 \%$ \\
\hline Truck & Nissan Truck & Nissan & $39.64 \%$ \\
\hline Bus & Hino & Hino & $80.56 \%$ \\
\hline Farm Tractor & Massey Ferguson & Millat & $51.44 \%$ \\
\hline
\end{tabular}


Source: Pakistan Automaitve Manufacturers Association [1]

At this point of time, it would be pertinent to use the Herfindahl Index (HHI) in order to find out the degree of competition in the sector. The index is used as measure of the size of firms and amount of competition between the firms. When the HHI was calculated for Pakistan's automobile industry, the following results were derived [2]:

- $\quad \mathrm{HHI}$ for $\mathrm{Cars}=4,948$

- $\mathrm{HHI}$ for LCVs $=5,400$

- $\quad$ HHI for Trucks and Buses $=3,950$

- $\quad$ HHI for Tractors $=4,250$

Analysis of HHI suggested that the industry had a tight oligopoly market structure with very high concentration ratios. Due to the high values of HHI, it is concluded that the auto market lacked free competition environment.

\subsection{High Protection Rate}

Trade liberalization is very important in today's open market environment. This enables the economies of large scale, optimum use of world resources, rise in demand for goods, increase in world's GDP and massive growth in investment level. Although the infant industry argument is valid for the economies like Pakistan, high protectionism is very difficult due to World Trade Organization. Moreover, it also rightly believed that long term trade barriers are just like slow poisoning to the industry that kill the production and innovation capabilities of the forms.

The automobile sector in Pakistan had been sheltered by many trade barriers to avoid foreign competition. Despite the high rate of protection, the import bill for the sector was quite substantial. Table 2 reflects that from 1996-97 to 2004-05, there was an upward movement in the import of automobile as the size inclined to $5.2 \%$ in 2004-05 from 2.44\% nine years ago. The import of vehicle was Rs.17,391.65 million in 1996-97 which reached the level of Rs. 63,494.67 million after nine years. The situation was not apparently favorable for the country and certain concrete measures were required to curtail the import bill on account of motor vehicles.

Table 2: Imports of automobile (in Rs. million)

\begin{tabular}{|l|l|l|l|l|}
\hline Year & Road Motor vehicles & $\begin{array}{l}\text { Road vehicles other than } \\
\text { motor vehicles }\end{array}$ & Total imports of vehicles & Share in total imports \\
\hline $\mathbf{1 9 9 6 - 9 7}$ & $14,883.715$ & $2,507.938$ & $17,391.65$ & $2.44 \%$ \\
\hline $\mathbf{1 9 9 7 - 9 8}$ & $13,087.189$ & $2,015.812$ & 1,5103 & $3.46 \%$ \\
\hline $\mathbf{1 9 9 8 - 9 9}$ & $13,518.813$ & $2,158.495$ & $15,677.31$ & $3.36 \%$ \\
\hline $\mathbf{1 9 9 9 - 0 0}$ & $15,534.822$ & $2,358.808$ & $17,893.63$ & $3.35 \%$ \\
\hline $\mathbf{2 0 0 0 - 0 1}$ & $16,180.616$ & $2,554.737$ & $18,735.35$ & $2.99 \%$ \\
\hline $\mathbf{2 0 0 1 - 0 2}$ & $17,567.650$ & $2,654.938$ & $20,222.59$ & $3.19 \%$ \\
\hline $\mathbf{2 0 0 2 - 0 3}$ & $25,791.307$ & $3,494.758$ & $29,286.07$ & $4.1 \%$ \\
\hline $\mathbf{2 0 0 3 - 0 4}$ & $32,467.918$ & $5,108.477$ & $37,576.4$ & $4.2 \%$ \\
\hline $\mathbf{2 0 0 4 - 0 5}$ & $56,836.478$ & $6,658.192$ & $63,494.67$ & $5.2 \%$ \\
\hline
\end{tabular}

Source" FBS [3]

\subsection{Effective Protection Rate (EPR)}

Effective Protection Rate states how much an industry is protected from the foreign competition. The automobile industry is assumed to be one of the most protected industries in the country. The industry comparatively enjoyed a very high effective protection rate. The table 3 reveals the effective protection rate for the industry in 1997.

Table 3: Effective protection rate to auto industry

\begin{tabular}{|l|l|l|l|l|}
\hline Vehicle type & $\begin{array}{l}\text { Import \% } \\
\text { CKD/ RM }\end{array}$ & $\begin{array}{l}\text { Tariff } \\
\text { CBU }\end{array}$ & $\begin{array}{l}\text { Tariff } \\
\text { CKD/ RM }\end{array}$ & EPR \\
\hline $\mathbf{1 5 0 0 ~ C C ~}$ & $70 \%$ & $150 \%$ & $32 \%$ & $425 \%$ \\
\hline 800 CC & $40 \%$ & $110 \%$ & $32 \%$ & $162 \%$ \\
\hline Tractrors & $20 \%$ & $35 \%$ & $32 \%$ & $36 \%$ \\
\hline Vendors using S-form & $30 \%$ & $45 \%$ & $20 \%$ & $56 \%$ \\
\hline Without S-form & $30 \%$ & $45 \%$ & $65 \%$ & $36 \%$ \\
\hline $\begin{array}{l}\text { Without S- form and competing against } \\
\text { smuggled items }\end{array}$ & $30 \%$ & $20 \%$ & $65 \%$ & $1 \%$ \\
\hline
\end{tabular}

Source: Pakistan and Gulf Economist

In the beginning of $21^{\text {st }}$ century, the effective protection rate (EPR) for automobile industry increased sharply which ranged from 701 per cent to 5,000 per cent [4]. The objective of such protection rate was to 
enable the industry to achieve the desired level of indigenization. However, the industry could not achieve the set target and it indulged in short term objectives of maximization of profit.

The high EPR made the local industry dull, uncompetitive and profit oriented. One important example in this regard is that Pak Suzuki Motor Company booked the profit of Rs.148.716 million in 2002 as against Rs.52.97 million in 2001 [5]. As a result, the experts and analysts charged the sector for creating monopoly, offering few choices to consumers, selling vehicles on higher prices and booking very high margin of profits. Further, the industry also entered into the post WTO scenario especially with the provisions of Trade Related Investment Measures (TRIMS) and Trade Related Intellectual Property Rights (TRIPS). In those circumstances, the sector was not likely to afford such a high rate of protection and the industry had to face a very difficult time from the giants of world's auto manufacturers. Regardless of the threats from WTO regime, there was immense pressure from the dealers of used cars who persuaded the authorities to allow the import of old and reconditioned vehicles. The dealers had always been attempting in the past to influence the authorities to get a favorable decision. Once they succeeded in their efforts, the government would be forced to allow the import of used vehicles with certain relaxed conditions. Therefore, the industry was required to take serious measures so as to stand confidently on its own toes to cope with the challenges.

\subsection{Low Indigenization Level}

During the period of 1995 and 2005, the industry could not achieve indigenization level. In this way, the industry would be able to reduce the reliance on import by producing more and more local contents for vehicles.

Table 4:Indigenization level in 1995

\begin{tabular}{|l|l|}
\hline Vehicle & Indigenization level \\
\hline Suzuki Mehran 800cc & $58 \%$ \\
\hline Suzuki Khyber 1000cc & $44 \%$ \\
\hline Suzuki Margalla 1300cc & $35 \%$ \\
\hline Suzuki Pick up 800cc & $52 \%$ \\
\hline Suzuki Potohar 1000cc & $35 \%$ \\
\hline Suzuki Van 800cc & $47 \%$ \\
\hline Toyota Corolla & $28 \%$ \\
\hline Honda Civic & $28 \%$ \\
\hline Tractor Massey Ferguson & $84 \%$ \\
\hline Tractor Fiat & $84 \%$ \\
\hline KIA Ceres & $26 \%$ \\
\hline Honda Motorcycles & $70 \%$ \\
\hline Yamaha Motorcycles & $70 \%$ \\
\hline Suzuki Motorcycles & $65 \%$ \\
\hline
\end{tabular}

Source: Pakistan and Gulf Economist [6]

The performance of the industry pertaining to indigenization had never been very good since 1949 . During 1960s, the indigenization level was just $40 \%$ for trucks \& buses and $20 \%$ for cars. In 1995, the deletion level for parts in different vehicles is depicted in Table 4.

In 1995, the government established a new body i.e. Engineering Development Board with a view to formulating the long term policies for the industrial sector. The board formed a committee called indigenization committee so as to prepare and monitor the new type of deletion program called "Industry Specific Deletion Program" (ISDP). The committee set the targets for the industry to achieve indigenization level up to a certain time period .

As against the targets set by the committee, the performance of the industry in 2002-03 was not up to the marks as shown in table 5. The industry was apparently far behind from achieving the desired targets in 200203 in most of the vehicles.

Table 5: Achievement of maximum local content levels (2002-03)

\begin{tabular}{|l|l|l|}
\hline S.No. & Vehicle & Percentage \\
\hline $\mathbf{1}$ & Cars & $56-70$ \\
\hline $\mathbf{2}$ & Tractors & $63.5-85.5$ \\
\hline $\mathbf{3}$ & Motor cycles & $81-88$ \\
\hline $\mathbf{4}$ & Light Commercial vehicles & $42.7-55$ \\
\hline $\mathbf{5}$ & Buses / Trucks & $46.5-48.5$ \\
\hline
\end{tabular}

Sorces: Ministry of Industries and Production [7]

As far as the localization of parts was concerned, the status of the vendors for different companies was as under: 
Table 6:Company wise vendor information 2004

\begin{tabular}{|l|l|l|l|l|}
\hline Name of the company & $\begin{array}{l}\text { Total } \\
\text { Vendors }\end{array}$ & $\begin{array}{l}\text { Deletion } \\
\text { status }\end{array}$ & $\begin{array}{l}\text { No. of parts } \\
\text { localized }\end{array}$ & Models \\
\hline Indus Motor Co. & 61 & $38 \%-55.5 \%$ & 1,100 & (All models) \\
\hline Pak Suzuki & 180 & $70 \%$ & 2,800 & (All models) \\
\hline Honda Atlas Cars & 77 & $60.00 \%$ & 699 & \\
\hline Dewan Farooq Motor & 107 & $37 \%-58 \%$ & 1,311 & \\
\hline Total & 425 & & 5,910 & \\
\hline
\end{tabular}

Sorces: Ministry of Industries and Production

During 2004-05, the indigenization level for different vehicles was improved slightly as shown below:

Table 7: Level of Indigenization 2005

\begin{tabular}{|l|l|}
\hline Type of vehicle & Indigenization level \\
\hline Passenger cars & Up to 72\% \\
\hline Light commercial vehicles & Up to 52\% \\
\hline Buses & Up to 52\% \\
\hline Tractors & Up to $85 \%$ \\
\hline Trucks & Up to 52\% \\
\hline Motor cycles & Up to $89 \%$ \\
\hline
\end{tabular}

Source: Indus Motors Company [8]

In spite of many efforts made by the authorities during different periods, the vehicles assembled in Pakistan were not competitive enough in the global market. Despite the implementation of Industry Specific Deletion Policy, the industry relied upon the imported contents for vehicles in form of completely knocked down (CKD) kits.

The state of industry in the manufacturing of automobile parts was not up to the mark. For instance, the basic component for the production of automobile was engine, but the industry used to import the engines in Completely Built up (CBU) condition. Similarly, most of the body components were imported in completely knocked down (CKD) form. However, the indigenization level for motorcycles and tractors was very much in accordance with the expectations.

\section{$2.4 \quad$ Under-Utilized Capacity}

The industry could not succeed to utilize $100 \%$ capacity. As depicted by table 8 , the unused capacity for cars was $9.9 \%$ and for heavy commercial vehicles, it was $64 \%$ and for Motorcycles it was $44 \%$.

Besides the capacity utilization according the type of vehicle, the company wise detail for underutilized capacity is also given in table 9. Gandhara Industries and Sind Engineering Ltd were on the top pertaining to the idle capacity.

Table 8: Vehicle wise-capacity utilization

\begin{tabular}{|l|l|l|l|l|}
\hline Vehicle & Capacity (units) & Production (units) & Idle capacity (units) & \% of Idle capacity \\
\hline CARS \& LCV & 215,000 & 193,695 & 21,305 & 9.90 \\
\hline HCV \& Buses & 15,000 & 5,343 & 9,657 & 64.38 \\
\hline Tractors & 50,000 & 48,887 & 1,113 & 2.22 \\
\hline Motorcycles & 925,000 & 404,876 & 43.77 \\
\hline
\end{tabular}

Source: PAMA

Table 9: Company wise-capacity utilization

\begin{tabular}{|l|l|l|l|l|}
\hline Company & Capacity (units) & Production (units) & Idle capacity (units) & \% of Idle capacity \\
\hline Pak Suzuki & 100,000 & 99,734 & 266 & 0.26 \\
\hline Indus Motors & 50,000 & 41,552 & 8,448 & 16.89 \\
\hline Honda Cars & 50,000 & 30,464 & 19,536 & 39.07 \\
\hline DFL & 15,000 & 17,972 & $-2,972$ & -19.81 \\
\hline Sind Engg. & 1,000 & 68 & 932 & 93.20 \\
\hline Hinopak & 2,000 & 2,167 & -167 & -8.35 \\
\hline Ghand.Nissan & 3,000 & 1,652 & 1,348 & 44.93 \\
\hline Ghand. Ind. & 1,800 & 48 & 1,752 & 97.33 \\
\hline Master Motors & 8,050 & 2,239 & 5,811 & 72.18 \\
\hline Millat Tractors & 25,000 & 24,313 & 687 & 2.74 \\
\hline Al-Ghazi & 25,000 & 24,574 & 426 & 1.70 \\
\hline Atlas Honda & 500,000 & 360,561 & 139,439 & 27.88 \\
\hline DYL & 200,000 & 74,423 & 125,577 & 62.78 \\
\hline Suzuki Bikes & 65,000 & 16,954 & 48,046 & 73.91 \\
\hline Pakistan Cycle & 60,000 & 14,804 & 45,196 & 82.32 \\
\hline Plum Qinggi & 100,000 & 17,198 & 82,802 & 82.80 \\
\hline Fateh Motors & 50,000 & 34,018 & 15,982 & 31.96 \\
\hline
\end{tabular}

Source : PAMA 


\subsection{Inconsistencies in Policies}

A consistence in policy framework brings about growth and prosperity. As far as the automobile sector of Pakistan is concerned, there were more than 30 policy changes from 1994 to 2000 as shown in figure 1 . Due to the volatile policy framework, the industry could not attain the prosperity. In 2000, the government adopted uniform policy framework for the sector which brought about tremendous growth in the sector.

\section{Source: Indus Motors}

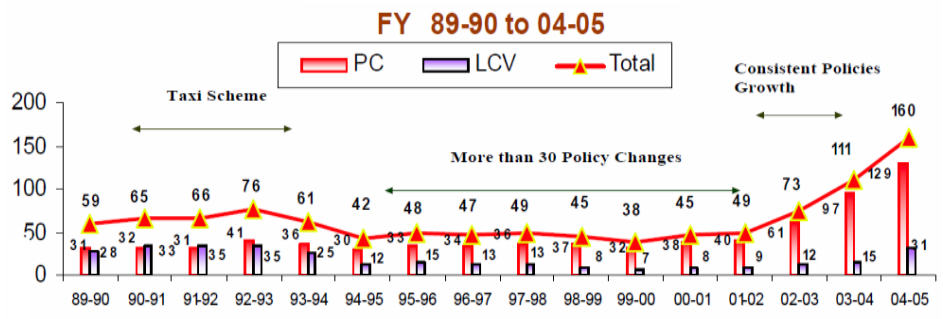

Figure 1. Policy Change and Growth

\subsection{Lack of Consumers' Sovereignty}

The automobile assemblers failed to offer vehicles at competitive price during the research period. The prices of units were comparatively higher than the price in the neighbor countries. The manufacturers had been giving some justification for charging high price such as high cost of raw material, increasing cost of energy and depreciation of domestic currency. All of these justifications were considered to be inevitable by the local companies. However, another important factor for high price was the cartel of the companies and their greed to maximization of profits. The assemblers were not willing to compromise on their high levels of profit. Hence, they used to create oligopoly and left few choices to the consumers. Further, the assemblers influenced the authorities to formulate such policies which were more beneficial to producers rather than consumers. In such a competitive global environment, the vehicle producers might not sustain their dictating position over the authorities and consumers in the long run.

\subsection{Poor Exploitation of Potential Demand}

Pakistan is one of those countries where there were around 8 cars per individual available for every 1000 persons. The ratio was very low as compared to other countries. The comparison between the status of motorization in Pakistan and other countries is depicted by following figure 2 which clearly depicts that the country had immense potential and demand for the automobiles.

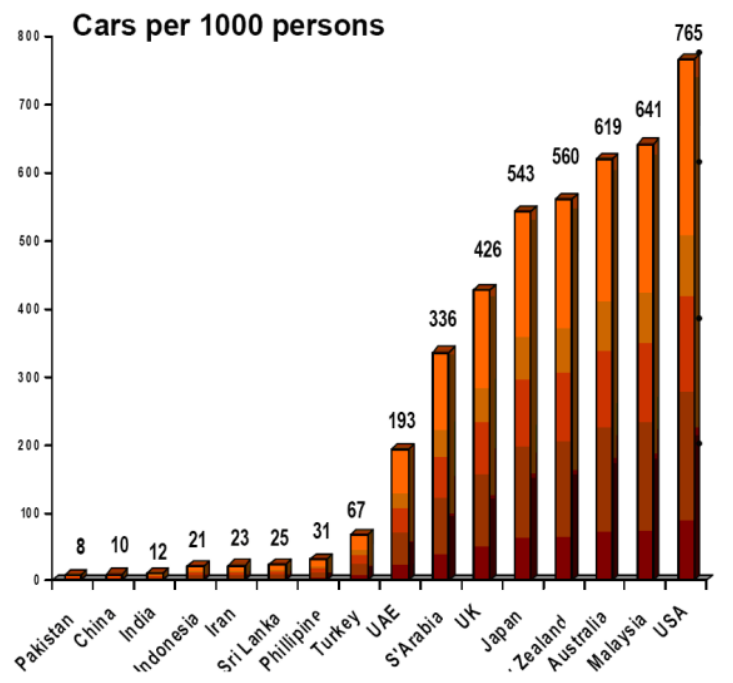

\section{Source: Indus Motors}

Figure 2 Motorization potential in Pakistan

Since transportation was becoming the need for daily life, the Original Equipment Manufacturers had a great opportunity to use the potential demand by means of effective marketing strategy, by improving quality of 
vehicles and by paying due respect to consumers. The automobile assemblers could not exploit the potential demand in the past sixty years properly.

\section{Conclusion}

On the basis of above analysis, we conclude that the automobile industry during the period of 1995 and 2005 faced many issues and problems. They include, under utilization capacity, low level of indigenization, lack of consumers' sovereignty, inconsistent policy framework and high protection rate. The responsibility lies on the shoulders of original equipment manufacturers, regulatory authorities and policy makers to realize the deficiency and take measures to cope with the situation.

\section{References}

[1] Pakistan Automaitve Manufacturers Association [PAMA].. Historical Data. 2009. Retrieved March 2, 2014 from PAMA website http://www.pama.org.pk/historicaldata.htm

[2] Qura-tul- Ain. Analysis of Pakistan Automobile Industry. Retrieved January 5, 2014 from scribd websitehttp://www.scribd.com/doc/3038403/AAAAPPPPPP, 2005

[3] Federal Bureau of Statistics. (2007). Pakistan Statistical Year Book Islamabad. Statistics Division, Government of Pakistan. 2007. pp 207-268. Retrieved June 20, 2013 from FBS website http://www.statpak.gov.pk/depts/fbs/publications/yearbook2007/foreign trade/9.5_.pdf

[4] Ghani M. Automobile Selection Policy: An Analysis. Centre for Management and Economic Research, Lahore University of Management Sciences. October 1997. Working Paper No. 97-15

[5] Pak Suzuki Company Ltd.(1995-2005). Annual Reports of the Company from1995 to 2005. Pak Suzuki Company Ltd., Bin Qasim, Karachi.

[6] Pakistan and Gulf Economist. Indigenization: Only a matter of will. (Jul 13 - 19, 1996). Retrieved August 6, 2013, from http://www.pakistaneconomist.com

[7] Ministry of Industries and Production. Digest of Industrial Sector, 2004. p.61. Retrieved June 5, 2013 from Government of Pakistan official website http://www.pakistan.gov.pk/divisions/industriesandproductiondivision/media/SectorsFile.pdf

[8] Indus Motors. Annual Reports of the Company from1995 to 2005. M/s. Noble Computer Services (Pvt) Ltd. Karachi 